\title{
Chromatographic separation and identification of many amino acid compounds of Leucaena glauca L. growing in Iraq
}

\author{
Ayad Al-Daoody ${ }^{1}$, Fanar Hashum AL-Hashemi ${ }^{2}$, Ahlam Ahmed Shehab ${ }^{1}$ \\ ${ }^{1}$ Department of Biology, College of Education, University of Mosul/Iraq. \\ ${ }^{2}$ Department of Horticulture and Landscape Design, College of Agriculture and Forestry, University of \\ Mosul/Iraq.
}

Rec. 15 Feb, 2013 Accept. 27 Mar, 2013

\begin{abstract}
The aim of the present study was to separation and investigation of many amino acids (glycine, aspargen, leucine, glutamic acid, proline, argenine, valine, alanine) from the leaves and seeds of leucaena glauca L. Amino acids were separated and investigated by highperformance liquid chromatography (HPLC) technique, which consisted of a UV-vis detector, C18, Mobile phase was $\mathrm{Na}_{2} \mathrm{SO}_{4}$. The result showed that the sample of chloroform extract of leaves was recorded of the highest quantity of aspargine $(43.725 \%)$, leucine $(8.905 \%)$ glutamic acid $(4.300 \%)$, while leucine, proline, alanine were recorded the highest quantity in seeds $(29.575 \%, 19.031 \%, 14.115 \%)$ respectively.
\end{abstract}

Key words: Amino acids, HPLC analysis, Leucaena glauca extracts.

\section{Introduction}

Leucaena is a genus of about 24 species of leguminous trees and shrubs, distributed from Texas U.S.A. to Peru, it belongs to the family leguminosae (Minari et al., 2012). Leucaena glauca can be used for several purposes such as live stock folder green manure or as a source of firewood and timber, provide shade for other plants as well as its function in maintaining the fertility of the soil (Hassan and Radwan, 2010).

Leucaena requires warm temperatures (25-30) ${ }^{\circ} \mathrm{C}$ for optimum growth so it's can be found performing well in a wide range of rainfall environments from 650 to $3.000 \mathrm{~mm}$, and grown in a wide variety of soil types including mildly acid soils $\mathrm{PH}>5.2$ (Oluwasola and Ayobore, 2004).

Leuacena seeds are ovoid in shape and have brown hulls and yellow kernels. The kernels have an oil content of $11.9-15.3 \%$ and a protein content of $52.5-66.4 \%$ (Mohamed and Khadiga, 2009).

Although there are differences in amino acids concentration between legumes, there may be much variation between samples of one legume (Evans, 1985). The amino acids content of grain legumes varies according to cultivar and environment (Wiryawan, 1997).

Leuacena's seeds are fairly rich in the essential amino acids but some of it such as isoleucine, leucine, phenyl alanine, histidine, lysine and methionine are also present in moderate amounts (Miranda et al., 2012).

The current study aimed to isolate and investigate some amino acid from leaves and seeds of Leucaena glauca by highperformance liquid chromatography (HPLC) technique.

\section{Materials and Methods: \\ Plant Material:}

During May 2013, leaves and seeds collected from tree Leucaena glauca at tenyear old which was growing in Mosul City.

The species was classified by Mr. Talal Taha that he is director of medicinal plant project of Mosul dam.

After air dried, the leaves and seeds were ground into fine powder and stored in a dark place until extraction was done.

\begin{tabular}{|l|c|l|}
\hline Kingdom & $:$ & Plantae-plants \\
\hline Subkingdom & $:$ & Tracheobionta-Vascular plants \\
\hline Superdivision & $:$ & Spermatophyta-Seed plants \\
\hline Division & $:$ & Magnoliophyta-Flowering plants \\
\hline Class & $:$ & Magnoliopsida-Dicotyledons \\
\hline Subclass & $:$ & Rosidae \\
\hline Order & $:$ & Fabales \\
\hline Family & $:$ & Fabaceae \\
\hline Subfamily & $:$ & Mimosoideae \\
\hline Tribe & $:$ & Mimoseae \\
\hline Genus & $:$ & Leucaena \\
\hline Species & $:$ & Leucaena glauca \\
\hline
\end{tabular}

Figure (1): Classification of Leucaena plant according to APG system III, 2009.

\footnotetext{
Corresponding author:

Dr. Ayad Al-Daoody

$\bowtie$ Ayad_khorsheed@yahoo.com
} 


\section{Preparation of amino acid extracts:}

Leaves and seeds of Leucaena glauca were extracted with $70 \%$ methanol in a soxhlet apparatus until no more colour was observed.

The methanolic extract was concentrated under reduced pressure to give $20 \mathrm{ml}$ oily material as crude extract with a yellowishgreen.

$10 \mathrm{ml}$ of the crude extract was dissolved in $25 \mathrm{ml}$ of aqueous methanol $(1: 1 \mathrm{v} / \mathrm{v})$, the slurry is filtered and the extract was shaken with chloroform $(2 \times 50 \mathrm{ml})$. the aqueous layer was examined for amino acids after concentration (Gulfraz et al., 2005).

\section{HPLC Analysis:}

According to (Schwarz, et al, 2005). the amino acids that containing in aqueous layer were confirmed by Shimadzu Lc-20AD (HPLC) equipped with a column (C18) and UV detector. Injection and detector temperature was $30^{\circ} \mathrm{C}$. The mobile phase was $40 \mathrm{mM} \mathrm{Na}_{2} \mathrm{HPO}_{4}$ (PH 6.8) adjusted with methanesulfonic acid (Table 1).

At this condition, amino acids were identified by comparison of their retention time $\left(\mathrm{R}_{\mathrm{t}}\right)$ with those of the standard compounds (Figure 3-10) and also quantified depending on peak area values.

\begin{tabular}{|l|l|}
\hline Properties & Analytical conditions \\
\hline Column & $\mathrm{C} 18(4.6 \times 240) \mathrm{mm}$ \\
\hline Mobile phase & $\begin{array}{l}40 \mathrm{mM} \mathrm{Na} \mathrm{HPO}_{4}, \mathrm{PH} \\
\text { adjusted at } 6.8\end{array}$ \\
\hline Temperature & $30^{\circ} \mathrm{C}$ \\
\hline Injection volume & $100 \mu \mathrm{L}$ \\
\hline Detection & $\mathrm{UV}$-vis \\
\hline Flow rate & $1 \mathrm{~mL} / \mathrm{min}$ \\
\hline Wave length & $210 \mathrm{~nm}$ \\
\hline
\end{tabular}

Table (1): The analytical condition of amino acids.

\section{Results and Discussions:}

The word proteins is derived from the (Greek) word proteins which means principal or prime, and amino acids are the monomeric units which derived of protein, the characteristics of amino acids are important to the structure and functions of the polymers (proteins), (Ahmed \& Abdelati, 2008).

In this study, HPLC-technique used to separation and investigation of many amino acids (glycine, aspargen, leucine, glutamic acid, proline, argenine, valine, alanine) from the leaves and seeds of Leucaena glauca (Figure 2).

All the main amino acids were identified in leaves such as aspargine $43.705 \%$; leucine $8.905 \%$ and glutamic acid $4.300 \%$ (Table 2), these values were superior to that obtained by Mohamed and Khadiga (2009) who showed that the leucaena seeds contained $1.80 \%$ leucine; $4.63 \%$ glutamic acid; $1.10 \%$ valine and alanine; $13.80 \%$ glycine; arginie $2.62 \%$.

The continuation of above work we found the presence of eight free amino acids in leaves, five of them were known leucine, proline, alanine, glutamic acid and valine were identify in seeds by comparing their $\mathrm{R}_{\mathrm{t}^{-}}$ values and the authentic sample (Figure 11), (Table 2).

Generally, the seeds have a few of a main metabolism because the absence of evaluators of photosynthesis to conformation the proteins. Consequently the existence of proteins is reflected the redundancy of amino acids that formed as a result of denaturation of proteins, while the leaves have abundance of amino acids outcome of completion the assessors of photosynthesis and formation of proteins.

The same results was obtained by Oluwasola and Ayobore (2004) when amino acids analysis by using high-performance liquid chromatography (HPLC) at wave length of $325 \mathrm{~nm}$ and an emission wave length $465 \mathrm{~nm}$, the column $(150 \times 4.6 \mathrm{~mm})$ and the mobile phase was 1,4-dioxan and 2propanol.
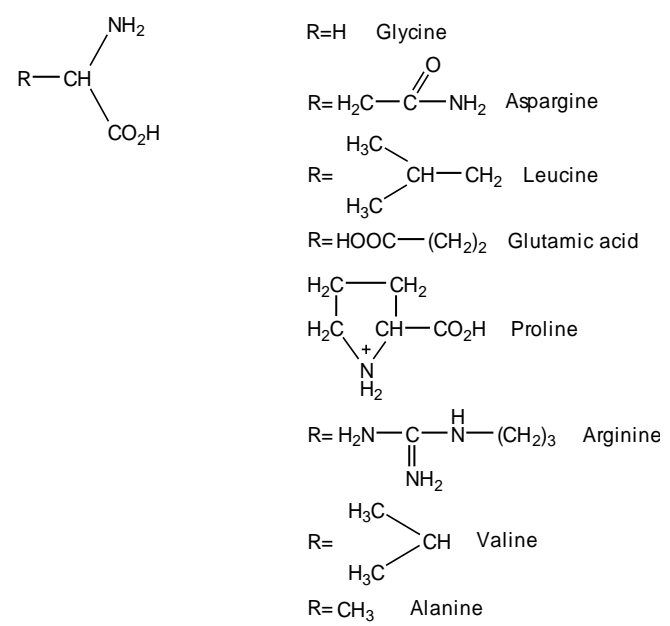

Figure (2): Formula of the amino acids that have been separated in the current study. 


\begin{tabular}{|c|c|c|c|c|c|}
\hline \multirow[b]{2}{*}{$\begin{array}{l}\text { Amino acids } \\
\text { compounds }\end{array}$} & \multicolumn{2}{|c|}{ Leaves } & \multicolumn{2}{|c|}{ Seeds } & \multirow[b]{2}{*}{$\begin{array}{l}\text { Standard } \\
\mathrm{R}_{\mathrm{t}}(\mathrm{min} .)\end{array}$} \\
\hline & Area $\%$ & $\begin{array}{c}\text { Compounds } \\
\mathrm{R}_{\mathrm{t}} \text { (min.) }\end{array}$ & Area \% & $\begin{array}{c}\text { Compounds } \\
\mathrm{R}_{\mathrm{t}} \text { (min.) }\end{array}$ & \\
\hline Glycine & 0.009 & 1.92 & $* *$ & $* *$ & 2.90 \\
\hline Aspargine & 43.725 & 2.93 & $* *$ & $* *$ & 2.83 \\
\hline Leucine & 8.905 & 3.24 & 29.575 & 3.12 & 3.12 \\
\hline Glutamic acid & 4.300 & 3.69 & 3.410 & 3.52 & 3.27 \\
\hline Proline & 2.024 & 4.00 & 19.031 & 3.65 & 3.84 \\
\hline Arginine & 0.441 & 4.57 & $* *$ & $* *$ & 4.07 \\
\hline Valine & 0.899 & 5.38 & 0.093 & 5.29 & 5.18 \\
\hline Alanine & 0.946 & 6.96 & 14.115 & 5.75 & 6.80 \\
\hline
\end{tabular}

Table (2): Amino acids that have been separated from the leaves and seeds of Leucaena glauca.

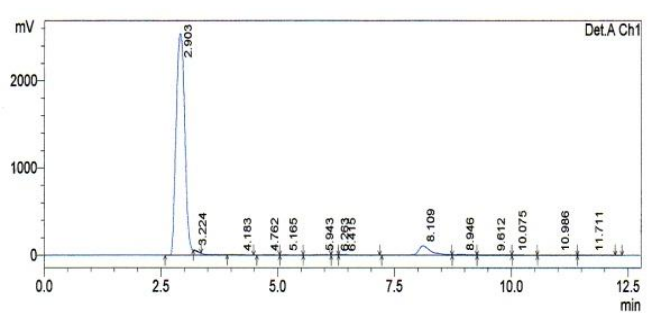

Figure (3): Chromatogram of glycine Standard, that appeared at 2.90 minutes by use $40 \mathrm{mM}$ $\mathrm{Na}_{2} \mathrm{SO}_{4}$ phase in HPLC technique.

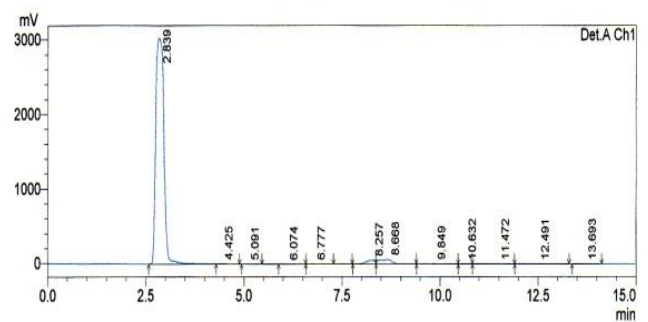

Figure (4): Chromatogram of aspargine standard, that appeared at 2.83 minutes by use $40 \mathrm{mM}$ $\mathrm{Na}_{2} \mathrm{SO}_{4}$ phase in HPLC technique.

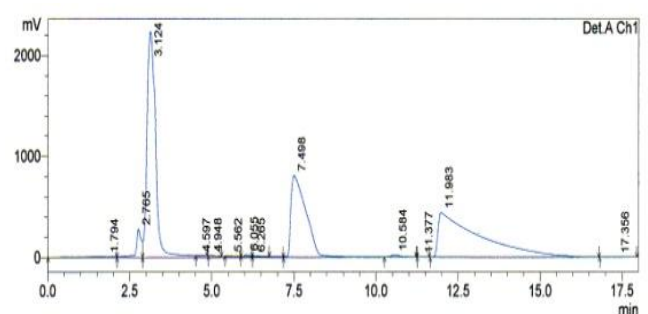

Figure (5): Chromatogram of leucine standard, that appeared at 3.12 minutes by use $40 \mathrm{mM}$ $\mathrm{Na}_{2} \mathrm{SO}_{4}$ phase in HPLC technique.

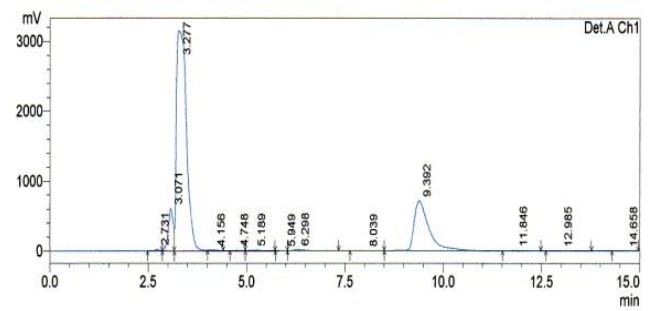

Figure (6): Chromatogram of glutamic acid standard, that appeared at 3.27 minutes by use 40 $\mathrm{mM} \mathrm{Na} \mathrm{SO}_{4}$ phase in HPLC technique.

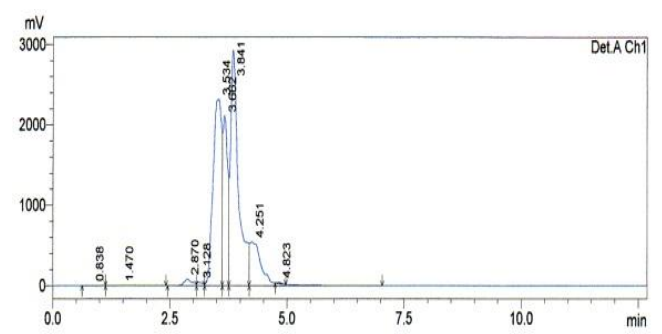

Figure (7): Chromatogram of proline standard, that appeared at 3.84 minutes by use $40 \mathrm{mM}$ $\mathrm{Na}_{2} \mathrm{SO}_{4}$ phase in HPLC technique.

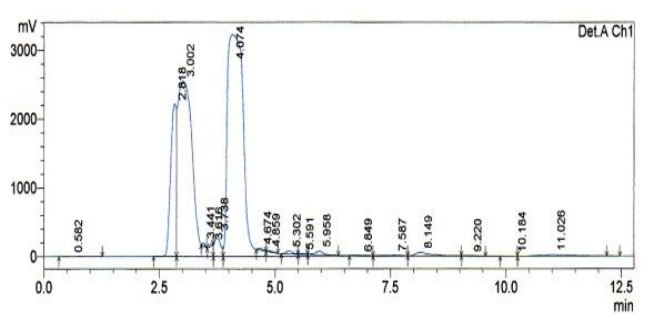

Figure (8): Chromatogram of arginine standard, that appeared at 4.07 minutes by use $40 \mathrm{mM}$ $\mathrm{Na}_{2} \mathrm{SO}_{4}$ phase in HPLC technique.

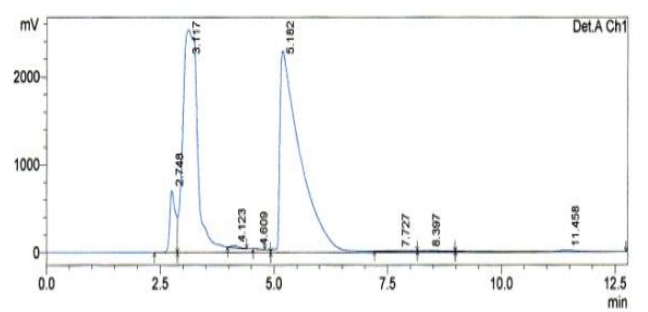

Figure (9): Chromatogram of valine standard, that appeared at 5.18 minutes by use $40 \mathrm{mM}$ $\mathrm{Na}_{2} \mathrm{SO}_{4}$ phase in HPLC technique.

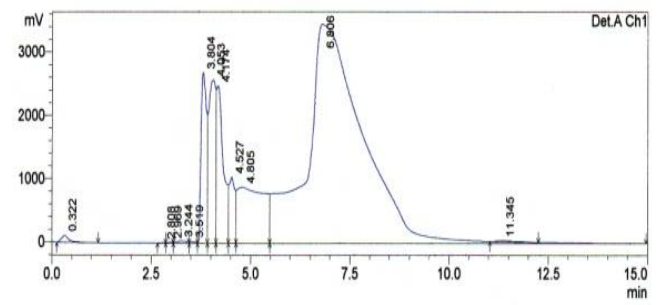

Figure (10): Chromatogram of alanine standard, that appeared at 6.80 minutes by use $40 \mathrm{mM}$ $\mathrm{Na}_{2} \mathrm{SO}_{4}$ phase in HPLC technique. 


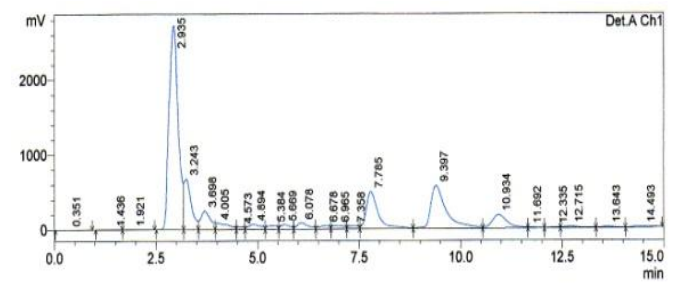

Figure (11): HPLC-Chromatograms of amino acids that have been extracted from Leaves of Leucaena glauca.

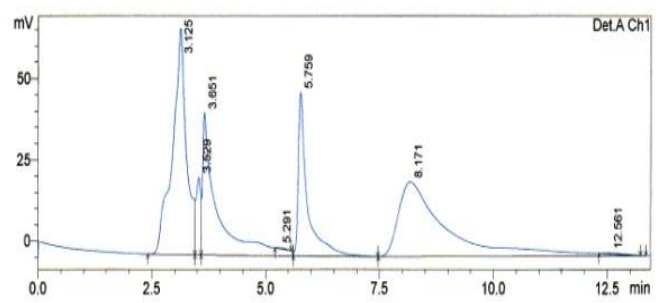

Figure (12): HPLC-Chromatograms of amino acids that have been extracted from Seeds of Leucaena glauca.

\section{References:}

Ahmed, M.E. and Abdelati, K.A. (2008). Effect of dietary levels of processed Leucaena leuaena leucocephala seeds on broiler performance and blood parameters. Int. J. Poult. Sci., 7(3): 423-428.

APGIII. (2009). "An update of the Angiosperm phylogeny group classification for the orders and families of flowering plants". Botanical J. of the linnean Society. 161: 105-121.

Schwars, E.L. et al. (2005). Analysis of plasma amino acid by HPLC with photodiode array and fluorescence detection. Clinica, Jamaica- Acta, 354: 83-90.

Evans, M.E. (1985). Nutrient composition of feeds tuffs for pigs and poulty. Queensland Department of Primary Industries, Pub. No. Q 15001, Brisbane.
Gulfraz, M., Arshad, M., Uzma, N. and Shabir, K. (2005). Comparison in Various Bioactive compounds of Leaves and Seeds of Foeniculum vulgare Mill. Ethnobotanical Leaflets, 9: 6-14.

Hassan, R.A. and Radwan, H.M. (2010). The lipids and volatile oil constituents of Leucaena glauca L. Benth. growing in Egypt and their Biological activity. Journal of Applied Sciences Research, 6(5): 478-482.

Minari, J.B., Odutuga, A.A., Bamisaye, F.A. and Dairo, J.O. (2012). Effect of some processing Techniques on the proximate and Antinutrients composition of Leucaena leucociphala seed. Pakistan Journal of Nutrition, 11(4): 310312.

Miranda, L.F., Norberto, M.R., Elzania, S.P., Roberto, D.S. and Particia, G.P. (2012). Chemical composition and ruminal degradation kinetics of crude protein and amino acids, and intestinal digestibility of amino acids from tropical forages. Revista Brasileira de Zootecnia, 41(3): 717-725.

Mohamed, E.A. and Khadiga, A.A. (2009). Chemical composition and Amino acids profile of Leucaena leucocephala seeds. International Journal Poulty Sciences, 8(10): 966-970.

Oluwasola, J.A. and Ayobore, V.A. (2004). Chemical characterization and protein quality evaluation of leaf protein concentrates from Glyricidia sepium and Leucaena leucocephala. International Journal of Food Science and Technology, 39: 253-261.

Wiryawan, K.G. (1997). Grain leaumes for poulty. PhD Thesis. University of Queensland. 


\section{الملخص العربى}

\section{الفصل والتشخيص الكروماتوغرافي لبص مركبات الاحماض الامينية لنبات اللوسينا النامي في العراق}

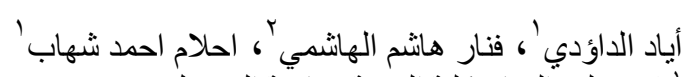

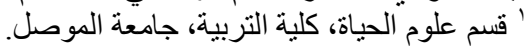

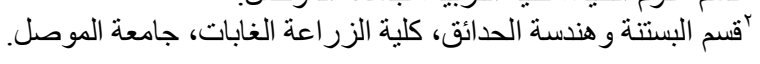

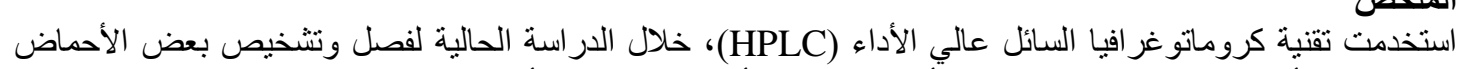

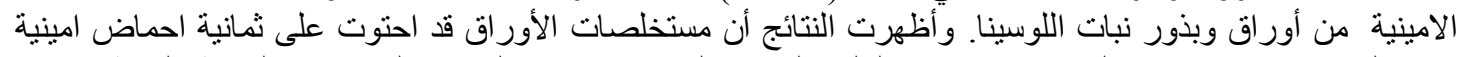

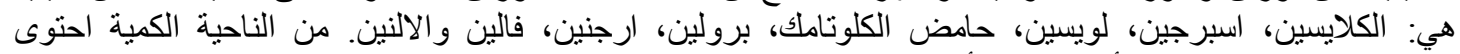

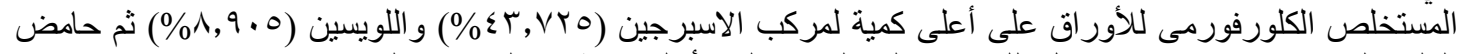

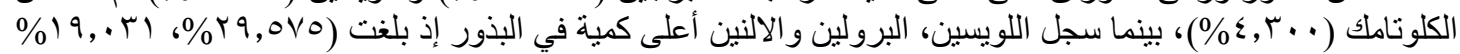

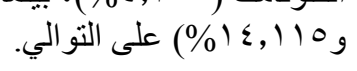

الكلمات الدالة: الأحماض الامينية، التحليل بـHPLCب، مستخلصات اللوسينا. 